\title{
REDES DE SOCIABILIDADE, IDENTIDADES E TROCAS GERACIONAIS Da "Cova da Música" ao circuito musical africano da Amadora
}

\author{
Pedro Varela \\ Centro de Estudos Sociais da Universidade de Coimbra (CES-UC)
}

Otávio Raposo

Instituto Universitário de Lisboa (ISCTE-IUL), Centro de Investigação e Estudos de Sociologia (CIES-IUL), Lisboa, Portugal

\section{Lígia Ferro}

Instituto de Sociologia da Universidade do Porto (IS-UP), Faculdade de Letras da Universidade do Porto, Porto, Portugal

Resumo As fronteiras geracionais são habitualmente apontadas como fatores de diferenciação social no que toca às práticas e construções de determinados géneros musicais e estilos de vida associados. A partir de uma pesquisa etnográfica realizada no bairro da Cova da Moura e noutros lugares do circuito musical africano da Amadora, protagonizado por imigrantes cabo-verdianos, concluímos que as sociabilidades e as trocas culturais entre artistas de várias gerações, muitas vezes estabelecidas a propósito da partilha de saberes relacionados com os usos das novas tecnologias, por um lado, e com a aprendizagem de instrumentos musicais, por outro, adquirem uma importância ímpar na construção das identidades sociais. Deste modo, salienta-se a centralidade da música nas trajetórias migrantes que se cruzam em vários espaços da Amadora.

Palavras-chave: música, migrações, gerações, etnografia urbana.

Abstract The generation borders are usually seen as factors of social differentiation in what concerns practices and constructions of certain musical genres and related lifestyles. Starting from an ethnographic research in the Cova da Moura neighborhood and other places of the musical circuit performed by Cape-Verdean immigrants working at Amadora, we conclude that the interchanges between artists from several generations, built from shared knowledge about new technologies and learning of traditional instruments, have a great importance in the construction of social identities. Thus the authors show how music is in the center of the migrant trajectories crossing several spaces of Amadora.

Keywords: music, migrations, generations, urban ethnography.

Résumé Les barrières générationnelles sont souvent citées comme des facteurs de différenciation sociale en matière de pratiques et de constructions de certains genres musicaux et styles de vie associés. En partant d'une enquête ethnographique dans le quartier de Cova da Moura et dans d'autres lieux du circuit musical des musiciens cap-verdiens habitant Amadora, nous concluons que les échanges et les mélanges culturels entre artistes de plusieurs générations, construites a propos du partage de connaissances sur l'utilisation des nouvelles technologies et l'apprentissage des instruments traditionnels, sont très importantes dans le procès de construction des identités sociales, ce qui montre l'importance de la musique dans les trajectoires migrantes en traversant plusieurs espaces d'Amadora.

Mots-clés: musique, migrations, générations, ethnographie urbaine.

Resumen Las barreras generacionales son habitualmente vistas como factores de diferenciación social en lo que toca a las prácticas y construcciones de determinados géneros musicales y estilos de vida asociados. A partir de una investigación etnográfica realizada en el barrio de Cova da Moura y otros lugares del circuito musical protagonizado por inmigrantes cabo-verdianos trabajando en Amadora, concluimos que las trocas y las misturas culturales entre artistas de varias generaciones, muchas veces establecidas a propósito del aprendizaje de saberes relacionados con las nuevas tecnologías y instrumentos tradicionales, adquieren una grande importancia en la 
construcción de las identidades sociales, revelando el papel central de la música en las trayectorias migrantes que se cruzan en varios espacios de Amadora.

Palabras-clave: música, migraciones, generaciones, etnografía urbana.

\section{Introdução}

Imigrantes cabo-verdianos e descendentes de várias gerações expressam-se musicalmente de formas diversas, adotando géneros musicais "clássicos" ou "tradicionais", cosmopolitas ou transnacionais (Sieber, 2005; Monteiro, 2011). ${ }^{1}$ Os géneros mais "clássicos" são expressões musicais como morna, koladera, funaná, batuke ou tabanka, e os de caráter transnacional são o rap, o zouk, a kizomba, o reggae, o kuduro ou o afro-house. ${ }^{2}$ Frequentemente, os primeiros géneros musicais são associados às gerações mais velhas e os segundos às mais novas, nomeadamente pelos média e pelos discursos de senso comum. Contudo, a investigação que está na origem deste artigo mostrou como a compreensão da realidade social exige modelos de análise mais complexos, que ultrapassem dicotomias reducionistas. Embora haja uma tendência para identificar géneros musicais específicos com diferentes faixas etárias ou gerações, todos os géneros são protagonizados por jovens e adultos, como veremos.

A idade, tempo de permanência no país de chegada e tempo de saída do país de origem têm uma relação com as configurações das práticas artísticas migrantes. No entanto, há outras variáveis que complexificam o modo como os recursos artísticos são incorporados e colocados em ação pelos indivíduos, entre os quais os estilos de vida, os percursos biográficos, as redes de sociabilidade e as estratégias de integração no contexto migratório. Assim, as produções musicais devem ser analisadas sob uma matriz não essencialista que tenha em conta as trocas culturais, possibilitadas pela capacidade dos atores de "manejar tipos simbólicos diferentes" e/ou criar produtos culturais híbridos a partir de múltiplas combinações possíveis (Hannerz, 1998: 37).

Este texto resulta do trabalho etnográfico realizado nos espaços do circuito musical africano da Amadora (cidade localizada nos subúrbios de Lisboa), no âmbito do qual percorremos os bairros da Cova da Moura, Seis de Maio, Estrela D'África e Reboleira. ${ }^{3}$ No decurso da etnografia, contactámos com jovens imigrantes que ao longo da sua trajetória artística escolheram tocar e ouvir funaná em vez de rap, rappers com mais de 40 anos de idade que, quando mais jovens, foram $D J s$ de

1 Lembramos aqui também, a título exemplificativo, a pesquisa de Rupa Huq (2003) sobre a new Asian dance music (NADM) e a música rap francesa, analisando a forma como estas culturas refletem as identidades (trans)nacionais europeias, apoiando-se na teoria pós-colonial.

2 Os géneros musicais serão escritos ao longo do artigo na sua forma linguística original.

3 "Reboleira" é a designação emic pela qual os habitantes da Estrada Militar do Alto da Damaia se referem ao seu bairro. 
kizomba, cantores de morna e koladera. Entre artistas de diferentes géneros musicais e gerações, as trocas e misturas são frequentes.

Partindo desta pesquisa, ${ }_{4}^{4}$ propomo-nos refletir sobre as relações de sociabilidade entre artistas imigrantes e/ou filhos de imigrantes cabo-verdianos de distintas gerações desenvolvidas no contexto de práticas musicais concretas, bem como sobre os processos de construção identitária que lhes estão associados. Estes atores não estão artificialmente separados, mas colaboram num circuito artístico que constantemente atualiza (e reinventa) as suas tradições (Hobsbawn, 1984).

\section{Mergulho no circuito musical africano da Amadora - abordagem metodológica}

Os cabo-verdianos são protagonistas de relevo no grupo dos artistas imigrantes do país, principalmente no conjunto daqueles que se dedicam à música (Nico, Rosado e Duarte, 2007). Para explorar etnograficamente o modo como estes atores constroem o seu quotidiano e o seu percurso como artistas, escolhemos o bairro da Cova da Moura, o qual se constitui como "[...] um dos espaços mais cabo-verdianos em Portugal" (Monteiro, 2011: 190), colocando o enfoque nos músicos, por estes serem os mais destacados atores artísticos deste circuito, assim como pelo facto de apresentarem um conjunto de atividades mais estruturadas no espaço e no tempo.

A Cova da Moura tem sido objeto de investimento analítico por parte de vários cientistas sociais portugueses, principalmente focalizando o rap e o graffiti como formas de expressão identitária dos jovens afrodescendentes (Vaz e Campos, 2013). A pesquisa etnográfica da qual se dá conta neste texto, estendeu-se para outros bairros da Amadora. Em primeiro lugar, acompanhámos os nossos atores nos seus trajetos de sociabilidade. Em segundo, seria errado circunscrever o nosso recorte etnográfico a uma parte da cartografia de uma realidade que a extravasa. Consequentemente, circular entre bairros permitiu-nos entender de uma forma mais ampla a realidade musical em estudo. Esta estratégia possibilitou uma melhor interpretação das práticas musicais na Cova da Moura e nos bairros da Amadora. Nesses trajetos, que ultrapassaram as fronteiras do "bairro", adotámos o conceito de circuito musical africano, ${ }^{5}$

4 A pesquisa que pretendemos colocar à discussão neste artigo foi desenvolvida no âmbito dos trabalhos do projeto "O Trabalho da Arte e a Arte do Trabalho. Circuitos Criativos de Formação e Integração Laboral de Imigrantes em Portugal", por Pedro Varela, Lígia Ferro e Otávio Raposo (estes dois últimos coordenadores do projeto). A investigação foi financiada pelo Alto Comissariado para as Migrações (ACM) e pela Comissão Europeia (CE) através do Fundo Europeu para a Integração dos Nacionais de Países Terceiros (FEINPT) e desenvolvida no âmbito institucional do Centro de Investigação e Estudos de Sociologia (CIES-IUL) do Instituto Universitário de Lisboa (ISCTE-IUL). Agradecemos a partilha de sugestões e comentários por parte dos restantes elementos da equipa de investigação (Pedro Abrantes, Graça Cordeiro, João Teixeira Lopes, Luísa Veloso, Magda Nico, Manuel Abrantes, Ricardo Bento e Tiago Caeiro).

5 Também nos movemos para o centro de Lisboa e para o Cacém. 
inspirando-nos na proposta de Magnani (2002), descrita pelo próprio nos seguintes termos:

[Circuito] "Trata-se de uma categoria que descreve o exercício de uma prática ou a oferta de determinado serviço por meio de estabelecimentos, equipamentos e espaços que não mantêm entre si uma relação de contiguidade espacial, sendo reconhecido em seu conjunto pelos usuários habituais [...] A noção de circuito também designa um uso do espaço e de equipamentos urbanos - possibilitando, por conseguinte, o exercício da sociabilidade por meio de encontros, comunicação, manejo de códigos" (Magnani, 2002: 23-24).

Por outro lado, tal como refere Ferro (2015), a existência de uma multiplicidade de movimentos por parte dos urbanitas exige uma abordagem etnográfica de "fluxos urbanos" que abranja vários territórios por onde transitam os protagonistas das práticas em estudo, desenvolvendo a chamada "etnografia móvel" (Pujadas e Maza, 2018).

Alguns locais da Cova da Moura fazem parte deste circuito, mas outros localizam-se em bairros como o Seis de Maio, o Estrela D' África, a Reboleira, entre outros. ${ }^{6}$ Cafés, restaurantes e bares com música ao vivo, estúdios de gravação e eventos festivos são lugares de criação, produção e exposição musical que constituem este circuito. Falamos de locais com enorme interconexão espacial e social. No âmbito deste circuito, notámos uma grande mistura geracional e de géneros musicais baseada em trocas constantes. A abordagem etnográfica a esta realidade permitiu-nos um entendimento "de perto e de dentro" (Magnani, 2002) do circuito em estudo. Durante o mergulho no terreno, que se prolongou de dezembro de 2014 a junho de 2015, desenvolvemos observação participante, dedicando uma grande atenção ao registo das nossas experiências em diário de campo. Realizámos e analisámos 17 entrevistas e também utilizámos a fotografia e o vídeo como ferramentas de recolha audiovisual, seguindo um percurso de encontro à sociologia e à antropologia visuais (Ferro, 2005).

No total, foram realizadas 42 idas a campo. Devido a outras pesquisas, trabalhos e amizades, este bairro já era um contexto familiar para os investigadores. Isso facilitou a nossa (re)entrada no bairro e permitiu-nos uma observação próxima, ao passo que articulámos a nossa pesquisa localizada com a escala urbana mais abrangente da qual o bairro faz parte integrante. Inicialmente falámos com os donos de estabelecimentos e com os músicos que aí atuavam. Posteriormente, abordámos as redes de sociabilidade entre gerações, entrevistando de forma mais aprofundada sete artistas. ${ }^{7}$ Gravámos também entrevistas com membros do Moinho da Juventude. ${ }^{8}$ Pelo facto de este ser um mundo artístico

6 O circuito musical africano da Amadora expande-se para outros bairros do concelho, como Casal da Mira, Casal da Boba e Santa Filomena. No entanto, focámo-nos nos lugares localizados nos bairros referidos porque foi onde os nossos atores nos levaram mais frequentemente.

7 As entrevistas tiveram um caráter marcadamente biográfico.

8 A Associação Cultural Moinho da Juventude foi criada em 1984 e é hoje uma instituição central para a vida do bairro. 
muito masculinizado (Monteiro, 2011: 86), devemos assinalar que foi apenas possível entrevistar três mulheres.

Pedro Diniz aka Machine, ${ }^{9}$ rapper da Reboleira e ex-produtor de um estúdio profissional do Moinho da Juventude, tornou-se um dos nossos informantes privilegiados e um ator fundamental da pesquisa. No primeiro encontro com Pedro, ele e outro colega de origem cabo-verdiana estavam a preparar a gravação de um videoclipe: tratava-se do primeiro single a solo de Márcio Freire, um artista com longa carreira na música popular cabo-verdiana. As primeiras imagens do single Ca$b o$-Verde foram gravadas nas margens do rio Tejo, nas ruas da Cova da Moura e zonas envolventes. Os sentimentos de saudade da terra natal e o sonho de retorno eram expressos na letra dessa música:

Ja'm kre bai pa Kabu Verdi I Pa'm bai mata nha sodadi I Pa viver mas a vontadi I Num pais di liberdadi I Kabu Verdi ke di meu I Ondi bu sta nha kretxeu I Mi ta lembra di Djeu I Tera bunitu sima ceu. ${ }^{10}$

Nesse dia, observámos com alguma surpresa, dois jovens artistas da cultura hip-hop ${ }^{11}$ produzirem um videoclipe de uma koladera nostálgica. Nesse momento, levantou-se a pista de trabalho sobre o papel das interações e das relações de sociabilidade intergeracionais na estruturação do circuito musical da Amadora.

\section{As gentes das ilhas e as suas musicalidades}

Artistas cabo-verdianos, santomenses, angolanos e guineenses estiveram presentes ao longo da pesquisa, mas foram os de Cabo Verde que protagonizaram a etnografia.

Desde o século XV que a as expressões culturais africanas fazem parte da cultura portuguesa: do vocabulário à religião, da literatura ao teatro e à música. ${ }^{12}$ Todavia, foi a partir dos anos 1960, com uma intensificação nas décadas de 1970 e 1980, após a descolonização, que teve início a migração laboral africana para Portugal, no âmbito da qual se destacam os imigrantes cabo-verdianos. É central o papel dos cabo-verdianos e seus descendentes na introdução do rap, soul, REB ou

9 Os nomes colocados no texto foram escolhidos e autorizados pelos próprios intervenientes.

10 "Quero regressar para Cabo Verde I Para matar minha saudade I Para viver mais à vontade | Num país de liberdade | Meu Cabo Verde | Onde estás tu meu amor | Eu lembro-me do "Ihéu" | Terra bonita como o céu" (https://www.youtube.com/watch?v=b7RzJwIswSI)

11 Esta expressão emic incorpora as quatro expressões artísticas que estruturam este movimento urbano: rap, DJing, break dance e graffiti.

12 Didier Lahon (2004) refere que a população africana e negra (escravos e livres) seriam aproximadamente $15 \%$ da população total de Lisboa entre o fim do século XVII e meados do séc. XVIII. São disso testemunho a toponímia da cidade (Rua Poço dos Negros e Rua das Pretas), as várias confrarias negras que aí existiram (Tinhorão, 1997) ou o antigo Bairro do Mocambo, então localizado no território da atual "típica" Madragoa (Coelho, 2014). 
zouk em Portugal; e hoje é comum ouvir referências ao funaná na música popular portuguesa. ${ }^{13}$

Atualmente vivem em Portugal entre 40.000 a 80.000 cabo-verdianos (Batalha e Carling, 2008: 68; SEF, 2013), um número que varia consoante o critério utilizado. ${ }^{14}$ Estes dados apresentam limitações, pois não incluem os imigrantes que obtiveram a nacionalidade portuguesa. Quando falamos das migrações do século XX, a deste arquipélago é das mais antigas em Portugal e encontra-se concentrada sobretudo na área metropolitana de Lisboa (AML), onde vive $82 \%$ da sua população. Os cabo-verdianos desempenham, maioritariamente, trabalhos não qualificados e desvalorizados socialmente (Oliveira e Gomes, 2014:39 e 65), muitas vezes na construção civil (no caso dos homens) e nos serviços de limpeza (no caso das mulheres) (Góis, 2008: 17).

No fim do século XX, dois terços dos cabo-verdianos viviam fora do arquipélago (Sieber, 2005), o que torna Cabo-Verde um dos países do mundo mais marcados pela migração (Batalha e Carling, 2008). A diáspora cabo-verdiana distribui-se por vários países, entre eles EUA, (onde vive a sua maior comunidade no estrangeiro), Holanda, França, Luxemburgo, Itália, São Tomé e Príncipe e Portugal, onde se encontra a sua maior população na Europa (Sieber, 2005: 123). Não é por acaso que o cosmopolitismo e a transnacionalidade cabo-verdiana se refletem profundamente nos sons criados pelos seus artistas e nas redes por eles estabelecidas. Assim, a música cabo-verdiana construiu-se híbrida, refletindo influências culturais diversas, desde África à Europa, passando pelas Antilhas e pelas Américas do Norte e do Sul. Essa influência transnacional intensificou-se e, nos dias de hoje, "a música cabo-verdiana, especialmente as formas mais contemporâneas e mutáveis, emerge em grande parte da diáspora, em vez de no próprio arquipélago" (Sieber, 2005: 126). Na diáspora cabo-verdiana novos estilos musicais surgem, mas os tradicionais mantêm-se, ${ }^{15}$ embora influenciados por sonoridades emergentes. ${ }^{16}$

A importância da música cabo-verdiana para a identidade da sua população foi salientada por parte significativa dos artistas entrevistados. É o caso de Zetatas Pretuguês, um músico da Cova da Moura de origem cabo-verdiana, que toca soul e reggae em bares do Cais do Sodré:

13 Ver: Némanus, Funana Contigo (https://www.youtube.com/watch?v=C7MUghLtN0Q) e Bruna Dançando o Funaná (https://www.youtube.com/watch?v=o8OdSWEXNqc).

14 OSEF considerava existirem 40.912 imigrantes cabo-verdianos em Portugal em 2014, 10,4\% do total de imigrantes no país, não contabilizando aqueles que já adquiriram a nacionalidade portuguesa.

15 Atualmente, segundo Sieber (2005: 125), uma maior ligação da juventude cabo-verdiana na diáspora com a migração transnacional africana e a identidade negra tem levado a uma adoção de géneros musicais como o rap e o zouk e também a um ressurgimento de estilos musicais tradicionais das "ilhas".

16 Protagonizado pelas gerações mais novas, o funaná eletrónico é emblemático das transformações mais recentes da musicalidade cabo-verdiana na diáspora, marcadas pela influência da música eletrónica e pelo maior acesso aos dispositivos tecnológicos e digitais. 
Eu sempre achei que o ouro ou o diamante de Cabo Verde fosse esse "cantar". [Entrevista a Zetatas Pretuguez, 39 anos, 27 de março de 2015]

Embora as relações intergeracionais na produção musical cabo-verdiana sejam pouco debatidas no âmbito académico, deparámo-nos, ao longo da nossa etnografia, com um quotidiano de trocas entre músicos de diferentes idades que favorecia a sua inserção no mundo artístico. Observámos como os músicos mais velhos, por vezes menos à vontade com as tecnologias digitais, aprendiam com os mais novos. Por outro lado, os "segredos" para tocar bem um instrumento musical eram partilhados pelos mais velhos com os mais jovens, conhecedores da música popular do seu país de origem. Sobre essa aprendizagem, Zetatas Pretuguez afirmou em entrevista:

O meu pai estava numa banda. Eu ia sempre com eles, curtia a cena toda e cantava desde puto. Estavam aqui sempre os instrumentos. Naquele tempo, quando um gajo tinha cinco ou seis anos, já estava aí com essa onda de tocar: os instrumentos de lata, ou ir para a bateria [...] fazia uns rifes de guitarra com a boca. Já cantava essas cenas que eles cantavam, eu sei tocar bué cenas deles atualmente [...] aquilo foram lições para um gajo. [Zetatas Pretuguez, 39 anos, 27 de março de 2015]

As interações culturais, a propósito das mais variadas práticas, têm o potencial de despoletar e fortalecer as relações intergeracionais (Ferro et al., 2014). Alguns músicos rompem fronteiras musicais com facilidade, atuando como mediadores entre culturas musicais distintas: autores de funaná amantes de reggae, intérpretes de koladeras que ao vivo tocam o estilo musical jamaicano, além de músicos mais jovens que optam por estilos mais tradicionais como o funaná. Este é o caso de Tony Fika, 30 anos, um reconhecido músico da Cova da Moura. Aos 19 anos começou a cantar ao vivo em cafés do bairro, motivado pela vontade de escapar ao duro trabalho na construção civil, onde não via perspetivas de futuro. Atualmente, a sua carreira de sucesso já o levou a atuar em França, Suíça, Espanha, Luxemburgo e Cabo Verde.

Nos bairros onde fizemos trabalho de campo, estúdios de rappers recebem artistas de música "tradicional", jovens artistas do $R \mathcal{E} B$ e da música rap assistem aos concertos de bandas de morna e koladera que enchem os cafés ao fim de semana. Estes exemplos demonstram que entre os que cá chegaram e os que cá cresceram se desenvolvem importantes interações e aprendizagens informais de "modos de fazer" (Certeau, 1980), que se tornam marcantes nas trajetórias pessoais e artísticas dos músicos imigrantes que integram o circuito da Amadora.

\section{Fronteiras geracionais permeáveis e múltiplas juventudes}

A juventude é fundamentalmente uma construção sociocultural e não uma condição natural e universal do desenvolvimento humano. O estudo pioneiro de Margaret Mead (1990) nas Ilhas Samoa demonstrou como as vivências da adolescência são profundamente marcadas pelo contexto sociocultural. Assim, o conceito de 
juventude adquire significados diferentes em cada sociedade, varia ao longo da história e depende das características sociodemográficas dos indivíduos. Para destacar essa heterogeneidade, vários autores construíram perspetivas plurais e abrangentes para conceber a juventude (Canclini, Cruces e Pozo, 2012; Feixa, 1999; Pais, 1993), incorporando a multiplicidade de identidades, de trajetórias e de projetos de vida (Velho, 1994) implicadas nas várias vivências da juventude.

Embora a idade seja um eixo estruturante na organização social de qualquer sociedade, a mesma tem fraco potencial explicativo na compreensão do conceito de juventude. A "juventude é apenas uma palavra", disse Bourdieu (2008) para colocar em evidência a subjetividade das divisões de idade e a necessidade de as pensarmos de modo articulado. Afinal, "somos sempre o jovem ou o velho de alguém" (2008: 143). Paralelamente, a condição natural (a idade) não coincide, necessariamente, com o estilo de vida e um conjunto de signos associados hegemonicamente à juventude. É nesse sentido que podemos dizer que há "jovens não juvenis" e "não jovens juvenis" (Margulis e Urresti, 1996: 22).

Diferente da idade cronológica, a abordagem das gerações relaciona-se com a história e a cultura de uma dada sociedade, enquadrando a socialização dos seus membros num contexto histórico específico. Por isso, as transformações de cada época tendem a produzir marcos interpretativos comuns a uma mesma geração, fruto de uma memória social partilhada. Podemos dizer que "cada geração pode ser considerada, até certo ponto, como pertencente a uma cultura diferente, na medida em que incorpora em sua socialização novos códigos e habilidades, linguagens e formas de perceber, de apreciar, de classificar e de distinguir" 17 (Margulis e Urresti, 1996: 18).

As sociabilidades e os estilos de vida experienciados nos grupos de pares ganharam maior relevo enquanto modelo de referência para os jovens nos dias de hoje, o que "continua a legitimar a admissão da hipótese segundo a qual algumas normas e padrões de comportamento geralmente aceites pelos adultos não são seguidos pelos mais jovens e vice-versa" (Pais, 1993: 43). Contudo, a "sucessão geracional" não pode ser tomada como o "eixo principal da mudança" (Feixa, 1993:34), já que não se pode atribuir, sem imensas contradições, um conjunto de interesses comuns - em termos de aspirações, expectativas e consumos culturais - a uma determinada faixa etária (Pais, 1993). Outras variáveis relevantes devem ser consideradas na análise da juventude, tais como geração, classe, género, território, etnia e estilo, claro está considerando a sua vinculação aos contextos históricos, culturais e sociais (Feixa, 1999). Nesta perspetiva, o tempo biográfico (curso da vida) e o tempo histórico (experiência histórica) sincronizam-se na noção de geração social (Mauger, 2013; Feixa e Leccardi, 2010).

Novas desigualdades e mudanças históricas têm vindo a relançar a discussão sobre os temas da juventude e geração. $\mathrm{O}$ alargamento a várias camadas da população do acesso às novas tecnologias que possibilitam comunicação à escala global estimulou um certo cosmopolitismo, marcado por processos de hibridização cultural,

17 Tradução livre dos autores. 
migração transnacional e precarização laboral (Feixa e Leccardi, 2010). Sobre estes processos são muitas as pesquisas que têm vindo a abordar a incerteza e reversibilidade dos processos de passagem para a vida adulta, em grande parte impulsionados pelas dificuldades de inserção laboral, num contexto onde imperam o desemprego e a precariedade (Calvo, 2011; Guerreiro e Abrantes, 2004; Lopes, 2000). Hoje, as fronteiras galgam-se constantemente, devido a "transições descontínuas" (Feixa, 2011), "ritos de impasse" (Pais, 2009) e uma certa "promiscuidade geracional", que tornam os atributos juvenis acessíveis independentemente da faixa etária (Vianna, 1997). Por isso, a ideia de coexistência entre gerações tem ganho terreno no debate científico atual. Esta perspetiva assume formas diversas, entre as quais: hospitalidade (Maffesoli, 2007), colaborações no âmbito das novas tecnologias (Pozo, 2012) e solidariedade (Feixa e Leccardi, 2010). Devido a um maior esbatimento das fronteiras geracionais, as definições de jovem e adulto tornaram-se crescentemente voláteis e flexíveis. Devido a este facto, investigadores como Carles Feixa (2011) questionam se ainda hoje podemos falar da juventude enquanto fase de transição para a vida adulta.

\section{A “Cova da Música” no circuito musical africano da Amadora}

A Cova da Moura é um bairro autoconstruído na Amadora, de população estimada entre 6 e 10 mil habitantes (Horta, 2008). Foi sobretudo a partir de 1974 que o bairro se desenvolveu, numa altura de forte explosão demográfica da AML, em que terrenos foram ocupados para dar lugar a moradias. A Cova da Moura não é um bairro único nas suas características, já que em seu redor existe um continuum de bairros de construção informal, como o Seis de Maio e a Reboleira, ou os já demolidos Estrela D' África e Fontainhas, todos datados da mesma época. Várias particularidades unem estes bairros, entre as quais serem habitados por uma população maioritariamente negra e africana, com destaque para a presença dos imigrantes cabo-verdianos, e para o facto de o crioulo cabo-verdiano ser a língua utilizada no quotidiano.

A segregação territorial e a discriminação racial afetam intensamente as populações destes bairros, responsabilizados pela insegurança que o "cidadão comum" enfrenta no seu dia a dia na cidade. $\mathrm{O}$ "processo de rotulagem" e a estigmatização (Goffman, 1988) desta população tem a ativa participação dos média (Batalha e Carling, 2008) e de determinados organismos públicos, corresponsáveis por legitimar uma atuação desproporcional e, muitas vezes, violenta da polícia, como relatam recentes reportagens da BBC, do jornal Público e da Rede Angola. ${ }^{18}$

18 Conferir Fletcher (2015), "They hate black people" (http://www.bbc.com/news/magazine-32419952), Henriques (2015), "Os polícias disseram que nós, africanos, temos de morrer" (http://www.publico.pt/sociedade/noticia/os-policias-disseram-que-nos-africanos-temos-de-morr er-1685599) e Raposo (2015), "Violência e racismo na Cova da Moura" (http://www.redeangola.info/especiais/violencia-e-covardia-na-cova-da-moura/). 


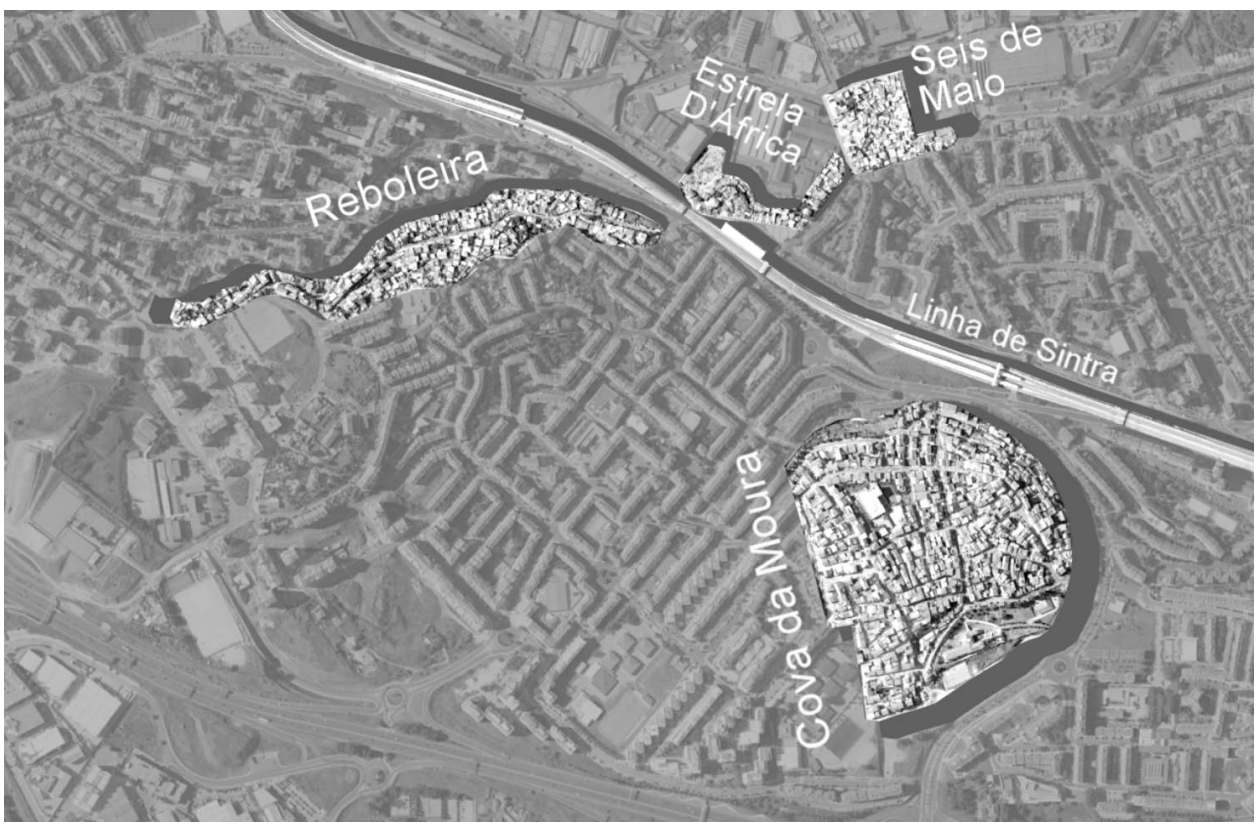

Figura 1 Mapa da Cova da Moura, Reboleira, Estrela d'África e Seis de Maio Fonte: Google Earth (relevo por Pedro Varela).

Entre os moradores dos bairros informais da Amadora foram criados fortes laços sociais, uma forma de enfrentar as desigualdades de poder e combater episódios de discriminação social e racial. Tais laços são também alimentados por relações de amizade e redes familiares comuns, amplificadoras de uma solidariedade e uma identidade étnica "baseada no sentido de pertença a uma coletividade com uma ascendência comum" (Pires, 2003: 100). O caráter relacional entre esses moradores é visível pelos trajetos constantes que fazem entre os bairros citados, promotores de um intenso intercâmbio de serviços e bens simbólicos, cartografia no âmbito da qual a Cova da Moura ocupa um lugar central. Este bairro distingue-se dos restantes pela sua maior dimensão, comércio mais diversificado, melhores infraestruturas e equipamentos sociais (ruas largas e asfaltadas, escola primária, infantário, etc.), para além de possuir um forte tecido associativo (Raposo, 2005; Horta, 2008).

Durante décadas, expressões artísticas originais desenvolveram-se nos bairros de forte presença africana dos subúrbios de Lisboa. Tradições dos países de origem e de destino misturaram-se, quando ritmos inovadores foram adotados e recriados por gerações distintas. Se estas artes para os mais velhos representam, muitas vezes, nostalgia e resistência cultural, para os mais novos por vezes revestem um significado simbólico de afirmação de uma negritude transnacional, transfronteiriça e transestética (Contador, 2001: 3), para além de resistência social (Raposo , 2010; Ferreira, 2010). 
Se percorrermos o bairro da Cova da Moura durante o fim de semana ficaremos surpreendidos com as inúmeras bandas que atuam em cafés, onde entre cerveja e grogue, os corpos se apertam para dançar. Aos sábados, quando o sol se põe, a música ao vivo invade as ruas do bairro e, das colunas de casas, bares e carros, ouvem-se batidas de rap, zouk ou afro-house e melodias de funaná, koladera e morna.

Em 2015, ano de realização da etnografia, eram cinco os estabelecimentos principais que ofereciam música ao vivo: o "Coqueiro", o "Santo Antão", o "João Roque", a "Princesa" e o "Terraço da Bibia". No "Coqueiro", jovens e graúdos bebem no balcão, alguns grupos jantam em mesas e os pares avançam para a dança.

No palco estão os "Brasa de Fogo", liderados pelo som da rabeca, ${ }^{19}$ cujas melodias nos remetem para as paisagens áridas do arquipélago. Não muito longe dali há também animação no "Santo Antão". Lá dentro, guitarrista e teclista, interpretam conhecidos temas de Cabo Verde. O público normalmente transborda para fora do estabelecimento, principalmente nas noites mais quentes. Se subirmos o bairro, podemos encontrar a "Princesa" numa noite de concertos, frequentemente funaná eletrónico. Os altos decibéis que de lá saem percorrem as ruas, criando o ambiente noturno que se vive na Praia, capital de Cabo Verde. Mais em baixo, no "João Roque", somos transportados para outro arquipélago, o de São Tomé e Príncipe. Em cima de um pequeno palco aglutinam-se os "MV4" com as suas guitarras, percussões e vocalistas, uma banda com um longo percurso que acabou de lançar o seu primeiro álbum. Conhecidos como os "Sacode Poeira de Portugal", os seus ritmos percorrem o socopé, o soukus, a rumba ou o zouk. No pequeno e mítico estabelecimento, homens e mulheres, jovens e seniores, maioritariamente santomenses, dançam em pares ou sozinhos, balançando os corpos ao ritmo das músicas eletrizantes das "ilhas maravilhosas". A noite acaba inevitavelmente no "Terraço da Bibia". A banda da casa, os "Convivências", fecha a animação musical do bairro com mornas e koladeras. Neste lugar juntam-se muitos artistas, alguns deles que já atuaram noutros locais ao longo da noite. Lá fora, do alto do "Terraço da Bibia" de onde se vê Benfica, Amadora e Odivelas, desaguam melodias sobre a noite da Grande Lisboa. Assim percebemos porque é que a Cova da Moura é, como nos disse um rapper do bairro, a "Cova da Música".

Este bairro é central na dinâmica musical cabo-verdiana da Amadora e também da AML. A maioria dos músicos que lá toca provém de outras zonas dos subúrbios de Lisboa, assim como parte significativa do público que para ali se desloca. Verificámos que a maioria deles conjuga o trabalho artístico com outros empregos, que vão da construção civil à hotelaria, dado que as quantias recebidas nessas atuações são irrisórias. São artistas por dedicação e "amizade à música", tal como os próprios referem.

As bandas são, maioritariamente, constituídas por elementos de uma geração mais velha, mas em alguns casos também incluem gente mais nova. É o caso, por exemplo, de um dos recentes guitarristas de "MV4", com 30 anos, ou de muitos dos

19 Rabeca é o nome pelo qual o violino é conhecido em Cabo Verde. No entanto, esta denominação é por vezes também utilizada em Portugal e no Brasil. 
artistas jovens de funaná eletrónico que atuam na "Princesa". A noite da Cova da Moura é frequentada quase exclusivamente por negros, em especial cabo-verdianos ou filhos destes, o que constitui um indício da segregação territorial eétnico-racial na área metropolitana de Lisboa. Cerca de 20 artistas atuam regularmente na Cova da Moura, e mais uma outra dezena toca e/ou canta esporadicamente. Entre os seus elementos existem os que cresceram em Portugal e os que emigraram adultos. A idade da maioria está acima dos 35 anos, embora por lá também passem muitos jovens, quando sociabilidades intergeracionais são postas em prática através da partilha de conversas, brindes e passos de dança. A entrevista a um cantor do bairro relata um pouco dessa dinâmica:

Acho que eles [jovens] gostam de nos ouvir, mesmo não sendo a música deles. Como nós sabemos, a música deles é o hip-hop, o reggae, essas coisas, mas gostam. Gostam de ouvir essas músicas. Gostam de estar ali a ver-nos. Alguns deles vêm dizer-nos: “Tu tocas bem! Tu cantas bem!" É uma coisa agradável de ouvir. [Entrevista a Carlos Santos (Galo), 40 anos, 22 de março de 2015]

Durante a semana vários grupos de dança de diferentes gerações ensaiam em salas do Moinho da Juventude, assim como as batukaderas do grupo Finka Pé. Este grupo de batuke surgiu na Cova da Moura em 1988 e é formado exclusivamente por mulheres de origem cabo-verdiana. Nas suas atuações dentro e fora do bairro, diferentes gerações partilham o mesmo palco, como é possível ver na figura 2, que ilustra uma apresentação do grupo no âmbito das festividades do Kola San Jon. ${ }^{20}$ Esta festa, agora património imaterial português, invade as ruas do bairro no mês de junho, onde crianças, jovens e seniores "ordenam" a dança com tambores e apitos, afirmando uma comunidade de pertença.

Os estúdios informais têm um papel importante para a comunidade artística imigrante, principalmente na última década, quando a popularização do acesso às novas tecnologias expandiu as possibilidades de gravação e difusão musical (Aderaldo e Raposo, 2016; Yúdice, 2007). Tais estúdios são muito comuns nos bairros visitados, sendo lugares onde se misturam artistas de diferentes musicalidades e idades. Este é o caso do Kova M Estúdio, um local central para a musicalidade da Cova da Moura e da Amadora, localizado nas instalações do Moinho da Juventude. Inaugurado em 2008, o aconchegante estúdio costuma juntar jovens todas as tardes para gravar rap e produzir os instrumentais (beats) que acompanham as suas músicas. Este recanto musical foi criado a partir da iniciativa dos rappers do bairro, em ligação com o Moinho da Juventude. É das salas do estúdio que surge parte significativa das novas sonoridades do bairro, principalmente o rape, mais recentemente, o afro-house. Os seus frequentadores são, sobretudo, jovens da Cova da

20 A Festa do Kola San Jon da Cova da Moura, inscrita desde de 2013 no Inventário Nacional do Património Cultural Imaterial Português, é um evento que se realiza por ocasião das festas de São João. Tem como elemento central um cortejo que "recria em contexto diaspórico, alguns aspetos da tradição cultural cabo-verdiana [...]" (Matriz PCI, 2015). Veja-se a propósito a dissertação de mestrado de Miguel (2010). 


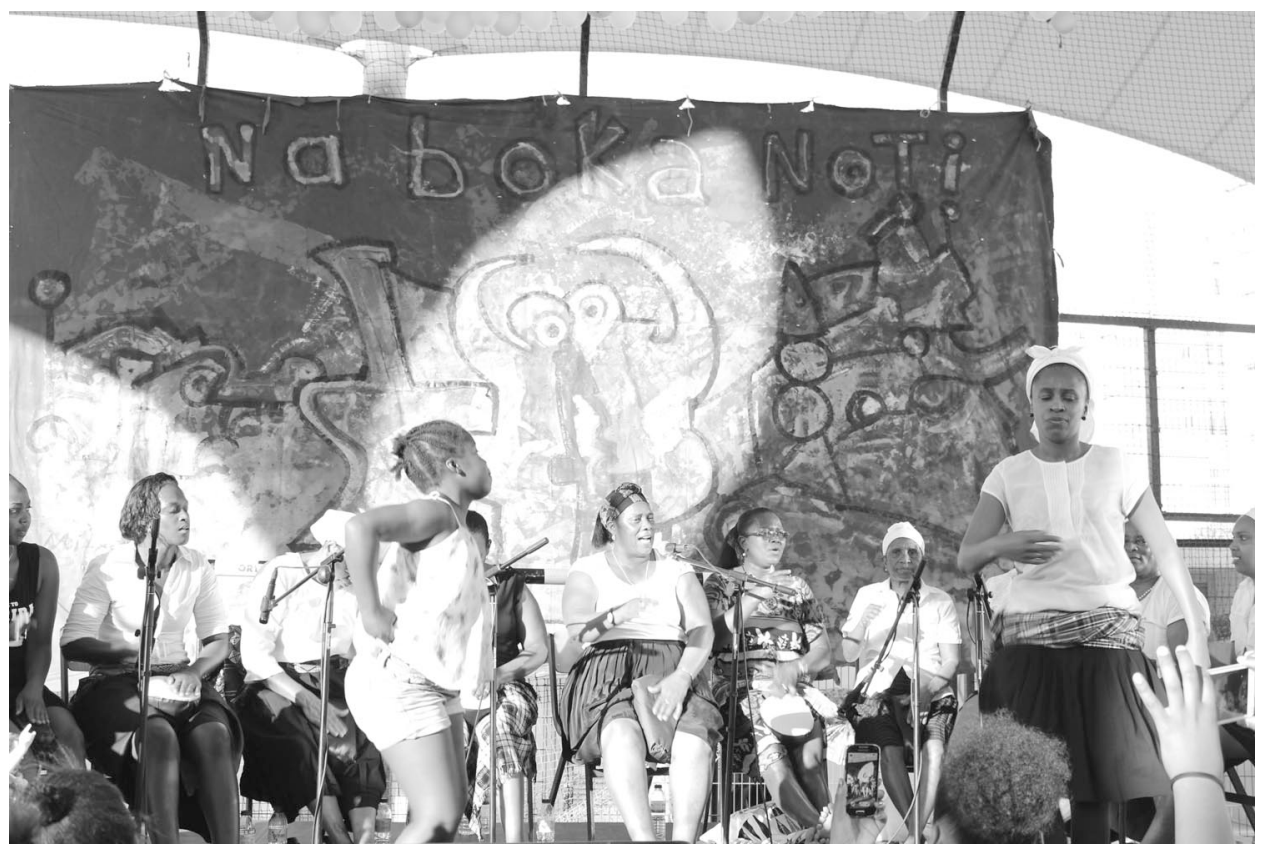

Figura 2 Várias gerações de mulheres numa atuação do Finka Pé

Fonte: Fotografia de Pedro Varela.

Moura do sexo masculino na faixa etária entre os 14 e os 24 anos. No entanto, este espaço também está aberto a artistas de fora do bairro e pertencentes a gerações mais velhas. A presença no estúdio de produtores oriundos de diversos bairros alguns deles com reconhecido capital simbólico na cultura hip-hop - é exemplar de como as expressões artísticas na Cova da Moura não podem ser pensadas isoladamente, mas integradas no circuito musical africano da Amadora e da AML.

As aprendizagens conjuntas e a troca de experiências entre músicos de diferentes faixas etárias, tanto residentes no bairro como fora dele, constitui uma das características mais interessantes do Kova M Estúdio. Entre os seus dinamizadores existe um esforço para favorecer as interações geracionais. Numa entrevista, um dos responsáveis pela criação do estúdio, rapper e funcionário do Moinho da Juventude, disse-nos o seguinte:

[...] os músicos rappers não têm muita cultura musical. A maior parte deles não sabe tocar, não conhece notas de música e esses músicos tradicionais conhecem. Então o objetivo que nós [promotores do estúdio] tínhamos proposto há dois anos atrás era criar mais essa fusão. Por isso é que comprámos equipamentos, jambés, guitarra, baixo, saxofone, que era para ver se criávamos mais essa fusão. [Entrevista a Lord Strike, 42 anos, 4 de março de 2015] 


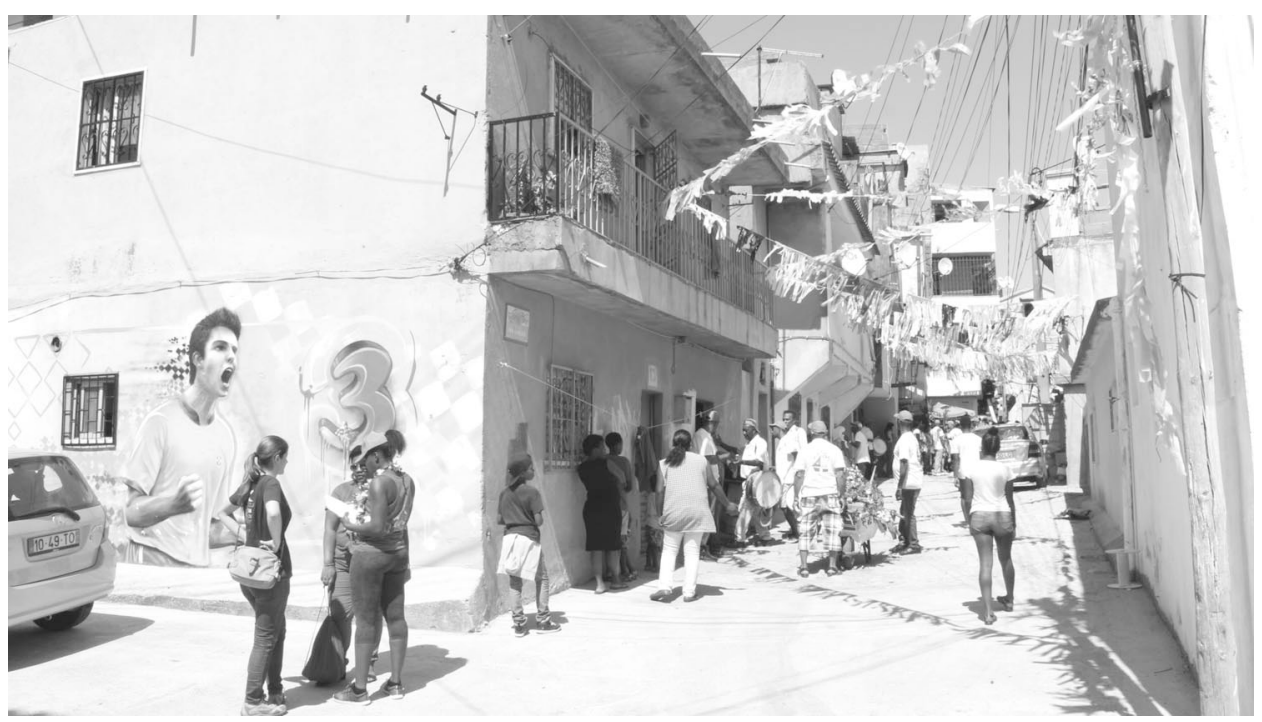

Figura 3 Cova da Moura no dia do Kola San Jon

Fotografia de Otávio Raposo.

Se o Kova M Estúdio é o locus privilegiado das novas sonoridades do bairro, o Kova M Festival representa o acontecimento extraordinário que condensa as experiências rotineiras de ensaio e gravação musical. Organizado pela juventude da Cova da Moura e apoiado pelo Moinho da Juventude, o Kova M Festival vai para a sua oitava edição e deve as suas origens a um conjunto de festas de hip-hop iniciadas nos finais dos anos 1990. Realizado no verão, este festival costuma durar uma semana com workshops de dança, graffiti, fotografia, literatura, passagens de filmes, desfiles de moda e uma ampla diversidade musical. O Kova M Festival culmina num fim de semana, quando artistas de toda a AML sobem ao palco num grande evento de exaltação das referências culturais negras e africanas, em que os jovens são protagonistas. Contudo, artistas mais velhos também costumam participar, como foi o caso das atuações em 2015 do grupo Finka Pé e do célebre músico cabo-verdiano Jorge Neto, ${ }^{21}$ que animaram o evento com batuke, funaná e zouk. A pertença a uma identidade negra transnacional e africana ${ }^{22}$ é comummente celebrada neste festival, quando jovens rappers e dançarinas de kuduro sobem ao palco, tal como músicos mais velhos que performam espetáculos de géneros musicais mais "tradicionais".

21 Jorge Neto, 50 anos, é um famoso artista cabo-verdiano que vive na Cova da Moura desde 2006, e cujas sonoridades misturam funaná e zouk.

22 O passado comum de escravidão, as experiências diaspóricas e, mais recentemente, a intensificação da globalização no "Atlântico Negro" (Gilroy, 2001), são as bases de uma cultura negra transnacional, cujo "banco de símbolos a qual recorrem é mais amplo e internacional do que nunca" (Sansone, 2007: 30). 
A etnografia estendeu-se também para um estúdio de cariz mais caseiro na Reboleira. Este foi construído por Pedro Diniz - rapper, produtor musical e de vídeo -, numa pequena divisão da sua própria casa. Por ali passam rappers, cantores de zouk, músicos "tradicionais", artistas africanos emigrados noutros países da Europa e amigos, misturando vários géneros, nacionalidades e gerações. Naquele local, num ambiente simultaneamente familiar e profissional, cria-se, grava-se, convive-se e estabelecem-se redes de sociabilidade que se alargam para além das fronteiras de Portugal.

Bares com música ao vivo, estúdios de gravação, restaurantes, cafés e eventos festivos são os lugares de criação e produção artística do circuito musical africano da Amadora, cujos limites se expandem para outros bairros como Casal da Mira, Casal da Boba e Santa Filomena. ${ }^{23}$ Entre versos, acordes e passos de dança, imigrantes e ascendentes de cabo-verdianos de distintas gerações inscrevem a materialidade desses bairros na urbe, em contraponto aos discursos que os situam "fora de lugar" (Agier, 2011: 127) da dita cidade formal e civilizada.

\section{Sociabilidades, aprendizagens e colaborações entre gerações de artistas}

A partir das interações e sociabilidades intergeracionais, práticas de colaboração e aprendizagem entre artistas imigrantes são construídas. Um dos acontecimentos presenciados no trabalho de campo revela a força dessas relações nos bairros estudados:

Naquele dia, num pequeno café da Cova da Moura, presenciei três gerações com bagagens musicais distintas a fabricarem novos sons. O Black Jesus, um jovem talentoso de 25 anos, era do rap/reggae. O Zetatas Pretuguez já contava com 39 anos e era um artista de soul/blues/reggae que acabava de lançar o single Soul Business. Como elemento central tínhamos o José, que já avançava para os 50 anos, percussionista da banda "Ferro Gaita", uma das bandas mais populares de funaná na atualidade. Os três percorreram diferentes terras. O primeiro foi de Lisboa para Cabo Verde e depois para o Luxemburgo, tendo regressado ao bairro há poucos meses; o outro nasceu em Lisboa e nunca foi às "ilhas", emigrou para o Reino Unido mas há alguns anos voltou a Portugal; o mais velho nasceu, cresceu e vive em Cabo Verde, estando de passagem por Lisboa para participar de um concerto no dia seguinte, em Nice (França). Os três, acompanhados pelos restantes frequentadores do café, criaram ali novas músicas, irrompidas das suas diferentes idades e géneros musicais. Os três trocavam conhecimentos e experiências, enquanto me indicavam notas e ritmos para a guitarra, depois de todos já terem passado nesse instrumento, os que sabiam e os que estavam a aprender. O que surgia ali era a música cabo-verdiana na sua transnacionalidade e fusão de estilos: das musicalidades tradicionais de Cabo Verde até às suas novas influências

23 Concentrámo-nos na Cova da Moura, no Seis de Maio e na Reboleira porque foi onde os nossos interlocutores nos levaram mais frequentemente.

SOCIOLOGIA, PROBLEMAS E PRÁTICAS, n.ำ 86, 2018, pp. 109-132. DOI: 10.7458/SPP2018867447 


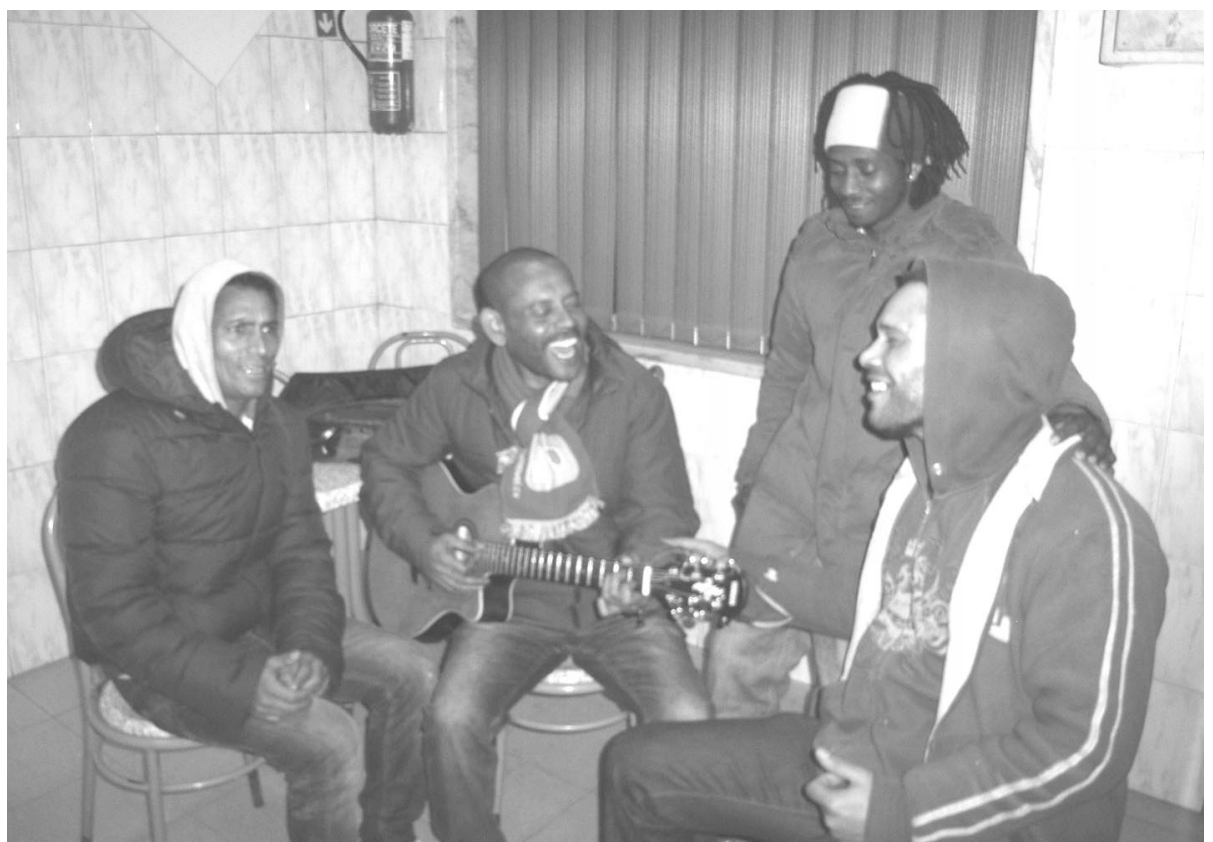

Figura 4 Interação entre gerações e géneros musicais no café "Coque Bafa"

Fotografia de Pedro Varela.

transnacionais, originárias das Antilhas e dos ritmos afro-americanos. O café "Coque Bafa" transformou-se durante uma noite num porto no meio do mar. Ali, atracaram os "vapores" 24 que levaram os cabo-verdianos para terras distantes, fugidos da miséria que as secas e o colonialismo provocaram. No porto, a diáspora desembarcou para fazer uma grande festa. Beberam, abraçaram-se e contaram histórias. Ali trocaram instrumentos, notas musicais e cantares das "ilhas" e dos portos distantes por onde andaram. Já de madrugada, embarcando em modernos "vapores aéreos" "abalaram" para terras distantes onde duras labutas os esperavam. [Diário de campo, Pedro Varela , 25 de março de 2015, Cova da Moura]

A troca de conhecimentos e aprendizagens entre gerações que observámos nesta noite foi a demonstração de que jovens e adultos não estão fechados nos seus campos artísticos, e de que existe uma aprendizagem contínua principalmente no campo da música, que se revela marcante ao nível da construção das identidades sociais e geracionais no âmbito das trajetórias migrantes que se cruzam no circuito musical africano da Amadora.

24 Oescritor Baltasar Lopes, no seu livro Chiquinho (2008), um dos mais emblemáticos da literatura cabo-verdiana, refere-se aos barcos a vapor que atracavam nos portos do arquipélago como "vapores". 
Para Pedro Diniz, as interações entre músicos de distintas gerações têm vindo a aumentar em Portugal, devido à maior aptidão dos mais jovens para o uso das novas tecnologias e à partilha destes conhecimentos com os músicos mais velhos. A interação entre elementos de várias faixas etárias dá-se a propósito da exploração das grandes potencialidades das novas tecnologias para a produção musical. Esta afirmação vai ao encontro da pesquisa de Maritza Pozo (2012) sobre a música popular alternativa mexicana, em que aponta as gerações mais novas como protagonistas das mudanças trazidas pelo impacto do acesso às redes digitais no consumo, produção e difusão musical. Um outro estudo refere que, em Portugal, as crianças e os jovens de famílias desfavorecidas lideram o grupo familiar no que diz respeito ao uso de novas tecnologias de informação e comunicação, o que não ocorre no seio de famílias com mais rendimentos, onde todos os membros manejam estas ferramentas (Almeida et al., 2013).

Cooperação e ajuda mútua entre músicos de gerações distintas ocorrem frequentemente, segundo Pedro Diniz, para quem a música "tradicional" se tornou uma referência nos seus projetos:

Já houve mais [separação entre gerações]. Houve uma fase em que estávamos mesmo distantes uns dos outros, mas acho que agora estamo-nos a juntar mais. Já vejo nós, os mais novos, ou os mais novos do que eu, a escutar mais a música tradicional. No meu tempo muitos não ouviam. Por exemplo, eu não ouvia. Hoje em dia o pessoal está a aderir mais à música tradicional, vai samplar ${ }^{25}$ música tradicional. [...] Eles nos ensinam bués, mas eles aprendem também. Fixe é que há uma troca de identidade ali muito boa. Nós estamos um passo à frente com a tecnologia, com o que é que podes fazer com um computador. Eles têm a música colada nos dedos, tu ficas mesmo de boca aberta. Tu vês pessoas tão simples como essas que tocam mesmo bem [...] e também te valorizam: a tua maneira de trabalhar e o que tu podes fazer por eles. Com respeito mesmo, tu vês aquele adulto a respeitar a tua cena. [Entrevista a Pedro Diniz, 30 anos, 3 de março de 2015]

As relações estabelecidas entre Pedro Diniz, de 30 anos, e Márcio Freire, de 52, são paradigmáticas de como artistas de diferentes gerações, preferências musicais e estilos de vida coexistem e se interconectam entre si num mesmo circuito artístico. Ao longo de vários meses, convivemos e participámos em alguns dos seus projetos.

Nascido em Angola, filho de pai cabo-verdiano e mãe angolana, Pedro Diniz veio viver para Portugal com sete anos, enquanto decorria a guerra civil angolana. Na Reboleira cresceu em estreita ligação com as referências culturais cabo-verdianas na diáspora. As roupas largas, geralmente associadas à estética hip-hop, a tatuagem e os cortes de cabelo e sobrancelhas denunciam uma certa estetização e estilização do seu modo de apresentação, a que se soma a importância dada por ele às atividades lúdicas, como a frequência de concertos, bares e festas.

Em contraste com Pedro Diniz, os valores hedonistas de Márcio Freire têm pouca importância no seu quotidiano, reflexo de um estilo de vida mais maduro e

25 Utilização de excertos de músicas para fazer novas composições (neste caso de rap), na maioria das vezes com o uso de um equipamento musical eletrónico chamado de sampler ou "caixa de ritmo". 


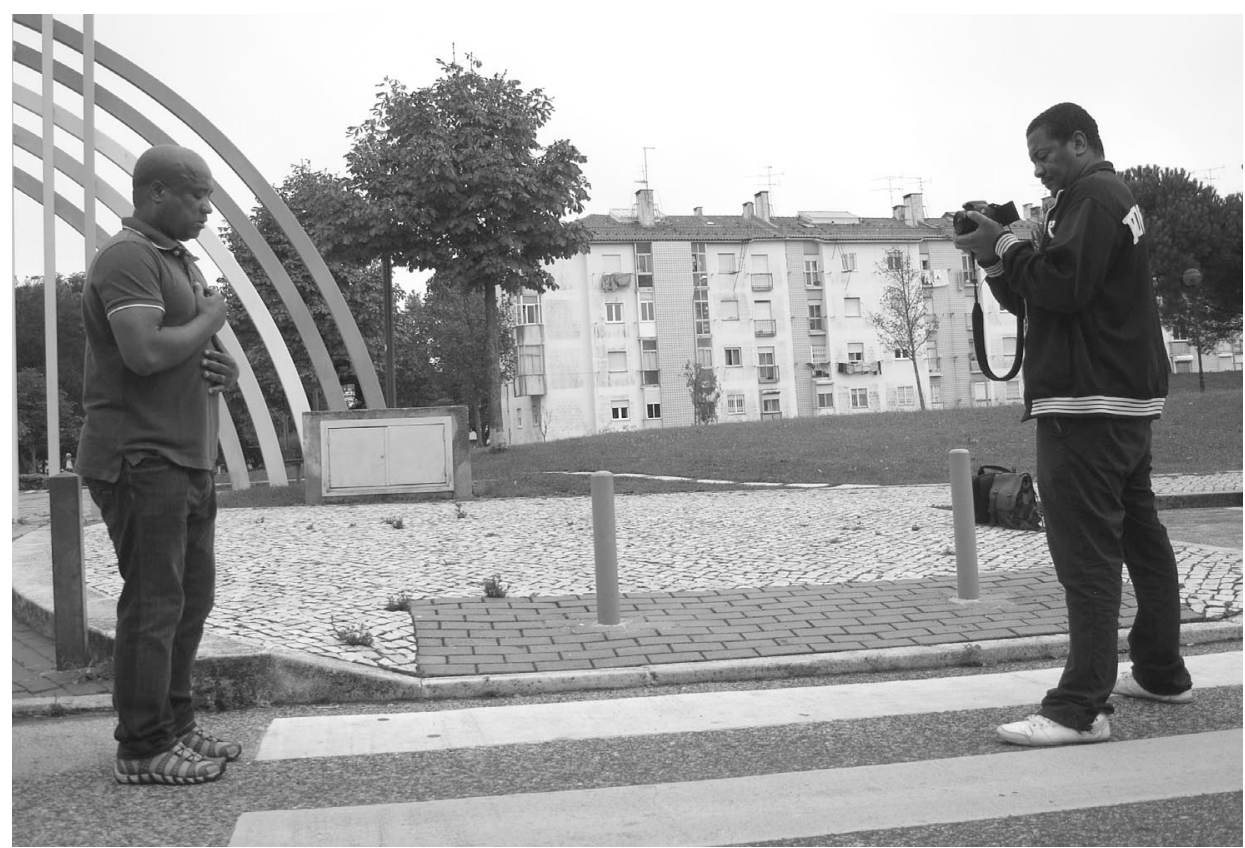

Figura 5 Pedro Diniz a filmar o primeiro videoclipe de Márcio Freire

Fotografia de Pedro Varela.

reservado. Márcio Freire saiu da ilha de Santiago com 13 anos e foi viver com um irmão em Roterdão. Após uma estadia de dois anos num país onde não se adaptou, veio para Portugal. Casado e com três filhos, Márcio viveu no Cacém e no bairro Seis de Maio antes de se mudar para a Cova da Moura. Influenciado pelo pai, que tocava concertina, a sua longa carreira musical iniciou-se em Portugal, onde em jovem teve lições de guitarra. Mais tarde, integrou diversas bandas e teve a oportunidade de tocar em lugares de referência para os artistas cabo-verdianos no centro de Lisboa e na Cova da Moura. No fim de 2014 lançou o seu primeiro álbum a solo: Pobreza.

Márcio e Pedro conheceram-se em 2009, quando o segundo, na altura monitor profissional do Kova M Estúdio, resolveu um problema no computador de Márcio. Mais tarde, voltaram a encontrar-se nas aulas de produção musical no Kova M Estúdio, onde Pedro era o principal responsável. Assim, foi na companhia de jovens que Márcio aprendeu os segredos de programas de produção musical. Hoje Márcio tem o seu próprio estúdio caseiro na Cova da Moura, onde grava tanto as suas músicas como a de outros artistas. ${ }^{26}$

26 A relação de Márcio com músicos de gerações mais novas já remonta há mais tempo. No seu terceiro single, por exemplo, arriscou-se a cantar rap, momento em que pediu o auxílio de um rapper da Cova da Moura dada a sua inexperiência com o estilo. Numa outra música do álbum teve a colaboração de um cantor de zouk de 17 anos do bairro de Santa Filomena. 
Ao descobrir a importância de ferramentas como o YouTube na difusão das suas músicas para chegar a novos públicos, Márcio convidou Pedro Diniz para realizar alguns dos seus videoclipes. Para Pedro, o trabalho com gerações mais velhas é uma oportunidade para ampliar o conhecimento musical, expandir redes de contacto e ganhar dinheiro extra no final do mês. Foram vários os videoclipes realizados por ele para artistas mais velhos, entre os quais os que se dedicam às sonoridades "tradicionais" africanas. O acesso constante às redes digitais permite a Pedro (e outros músicos) entrar em redes internacionais, tornar-se um artista mais eclético, e isso "reinterpreta o sentido do trabalho colaborativo entre gerações e disciplinas" (Canclini, Cruces e Pozo, 2012: 9). Essa capacidade de transitar entre diferentes "mundos da arte" (Becker, 1982) é exemplar do posicionamento de Pedro no centro de uma plataforma giratória multigeracional, multidisciplinar e transnacional, capaz de aproximar estilos musicais e diferentes gerações.

A relação entre esses dois artistas de origem imigrante é uma demonstração de cooperação, interdependência e aprendizagem mútua, apesar dos percursos, idades e estilos de vida distintos. No âmbito das colaborações empreendidas, alargam os seus horizontes artísticos e fomentam partilhas de conhecimento expansivas dos "campos de possibilidades" destes atores (Velho, 1994), incluindo os de cariz laboral.

\section{Considerações finais}

A ideia de que existe uma maior permeabilidade entre gerações tem vindo a ganhar força em virtude dos resultados alcançados em estudos recentes. Uma das mais importantes evidências prende-se com o facto de que as fronteiras geracionais se tornaram mais ambíguas. Se a mercadorização dos atributos juvenis revela os desejos da sua apropriação por outras camadas etárias, a crescente indefinição das trajetórias para a vida adulta denuncia bloqueios e incertezas num ambiente social marcado pela precariedade e pelo desemprego. ${ }^{27}$

A diversidade de estilos juvenis é acompanhada por fronteiras mais fluidas no que se refere aos marcos geracionais e ritos de transição para a vida adulta (Pais, 2009). Mais fragmentadas e menos padronizadas, essas transições dão origem a gerações liminares como a de "jovens adultos", o que se reflete na construção identitária e no próprio self. Este é o caso de um dos nossos entrevistados, Lord Strike, rapper, com 42 anos, que se assume "super jovem", apesar dos cabelos brancos.

No circuito musical africano da Amadora, observámos densas sociabilidades entre jovens, adultos e seniores, que se afirmam em trânsitos, aprendizagens e trocas simbólicas entre artistas de culturas musicais e gerações diversas. A música desempenha uma centralidade ímpar nos processos de construção das identidades

27 Segundo a Organização Internacional do Trabalho (OIT), dois em cada cinco jovens no mundo não trabalham ou têm trabalho tão mal pago que não conseguem escapar da pobreza. Para mais informações consultar: http://www.ilo.org/global/about-the-ilo/newsroom/news/ WCMS_447516/lang-en/index.htm 
sociais e geracionais. Neste contexto, compreender as diferenças de estilos de vida entre os músicos pode ser uma importante ferramenta para não ficarmos presos à variável etária. Por outro lado, esta categoria permite também verificarmos certas continuidades e mudanças geracionais nas preferências estéticas e nas culturas musicais nas quais os artistas se envolvem. É o que podemos deduzir da fala de LBC, que sublinha a influência crescente da música "tradicional" entre os músicos da sua geração, mesmo entre aqueles que optam pelo sampler e por ritmos transnacionais. Nestes casos, a mistura e o hibridismo dão azo a novos ritmos musicais que fogem às lógicas de tipo dual global/local.

Agora há rappers crioulos que andam a misturar a música de Cabo Verde com o rap. Pessoas de Angola andam a fazer misturas entre a dita música tradicional de Angola com o rap. Mas cada geração tem o seu próprio estilo né? [...] A gente faz o rap, a gente é hip-hopper, vive o hip-hop, vive a cultura, mas a gente também não deixa de viver a cultura de nossos pais. Até porque, e isso é interessante, nós estamos em Portugal, mas fazemos o rap em crioulo. [Entrevista a LBC, 33 anos, 3 de março de 2015]

Seguindo as pistas de Kiwan e Meinhof (2011), que indicam que surgem novas sociabilidades e mobilidades a partir de interfaces sociais, culturais, históricas e políticas entre a música e as migrações, acrescentamos que também são criadas novas formas de interação geracional a partir deste cruzamento. As interações e sociabilidades intergeracionais entre os músicos imigrantes cabo-verdianos e os seus descendentes não podem ser descontextualizadas, uma vez que se enquadram em redes de procura de trabalho e estímulo do crescimento artístico e, também, de fortalecimento identitário. Para estes atores, as relações intergeracionais são uma condição de alargamento de horizontes musicais e laborais através de aprendizagem, expansão e diversificação artística. Para os que cá cresceram ou vieram ainda jovens é também uma forma de encontrar "o seu lugar" e construir a identidade enquanto sujeito coletivo. Neste processo, a música é o lugar privilegiado da memória (e da diáspora), onde sentimentos e imaginários convocam todos a pensar sobre a sua origem, a sua história e o seu lugar no mundo.

\section{Referências bibliográficas}

Aderaldo, Guilhermo, e Otávio Raposo (2016), “Deslocando fronteiras: notas sobre intervenções estéticas, economia cultural e mobilidade juvenil em áreas periféricas de São Paulo e Lisboa", Horizontes Antropológicas, 22 (45), pp. 279-305.

Agier, Michel (2011), Antropologia da Cidade. Lugares, Situações, Movimentos, São Paulo, Editora Terceiro Nome.

Almeida, Ana, Nuno Alves, Ana Delicado, e Tiago Carvalho (2013), “Crianças e internet: a ordem geracional revisitada”, Análise Social, XLVIII (2), pp. 340-365.

Batalha, Luís, e Jørgen Carling (orgs.) (2008), Carling Transnational Archipelago. Perspectives on Cape Verdean Migration and Diaspora, Amesterdão, Amsterdam University Press. 
Becker, Howard (1982), Art Worlds, Berkeley, The University of California Press. Bourdieu, Pierre (2008), Cuestiones de Sociología, Madrid, Ediciones Istmo.

Calvo, Enrique (2011), "A roda da fortuna: viagem à temporalidade juvenil”, em José Machado Pais, René Bendit e Vítor Ferreira (orgs.), Jovens e Rumos, Lisboa, Imprensa de Ciências Sociais, pp. 39-57.

Canclini, Néstor García, Francisco Cruces, e Maritza Urtega Castro Pozo (orgs.) (2012), Jóvenes, Culturas Urbanas y Redes Digitales, Madrid, Fundación Telefónica.

Certeau, Michel (1980), L'Invention du Quotidien. “Arts de Faire”, vol. I, Paris, Gallimard.

Coelho, Alexandra Prado (2014), “Mocambo o bairro mais africano da cidade”, Público 13/07/2014 (página consultada em novembro de 2015).

Contador, António Concorda (2001), Cultura Juvenil Negra em Portugal, Oeiras, Celta Editora.

Feixa, Carles (1993), La Joventut com a Metáfora, Barcelona, Generalitat de Catalunya/ Secretaria General de Joventut.

Feixa, Carles (1999), De Jóvenes, Bandas y Tribus, Barcelona, Ariel.

Feixa, Carles (2011), “Tarzan, Peter Pan, Blade Runner: relatos juvenis na era global”, em José Machado Pais, René Bendit e Vítor Ferreira (orgs.), Jovens e Rumos, Lisboa, Imprensa de Ciências Sociais.

Feixa, Carles, e Carmem Leccardi (2010), “O conceito de geração nas teorias sobre juventude", Sociedade e Estado, 25 (2), pp. 185-204.

Ferreira, Vítor Sérgio (2010), “Cenas juvenis, políticas de resistência e artes de existência", Trajectos - Revista de Comunicação, Cultura e Educação, 16, pp. 111-120.

Ferro, Lígia (2005), "Ao encontro da sociologia visual", Sociologia, Revista da Faculdade de Letras da Universidade do Porto, 15, pp. 373-398.

Ferro, Lígia (2015), “Jump Lisbon! Notes from an ethnography of urban flows”, Portuguese Journal of Social Science, 14 (2), pp. 177-192.

Ferro, Lígia, Pedro Oliveira, Sara Trindade, e Susana Peixoto (2014), “Vive o bairro!” A intervenção comunitária como ferramenta da redução de riscos e minimização de danos na Matriz H do Bairro da Flamenga", Fórum Sociológico, 25, pp. 63-72.

Fletcher, James (2015), “They hate black people”, BBC News, 23/01/2015, consultado a 10/05/2015, em: http://www.bbc.com/news/magazine-32419952

Gilroy, Paul (2001), O Atlântico Negro. Modernidade e Dupla Consciência, São Paulo, Editora 34.

Goffman, Erving (1988), Estigma. Notas sobre a Manipulação da Identidade Deteriorada, Rio de Janeiro, Jorge Zahar Editor.

Góis, Pedro (org.) (2008), Comunidade(s) Cabo-Verdiana(s). As Múltiplas Faces da Imigração Cabo-Verdiana, Lisboa, Alto Comissariado para a Imigração e Diálogo Intercultural (ACIDI).

Guerreiro, Maria das Dores, e Pedro Abrantes (2004), Transições Incertas. Os Jovens Perante o Trabalho e a Família, Lisboa, Presidência do Conselho de Ministros, Ministério das Actividades Económicas e do Trabalho, Comissão para a Igualdade no Trabalho e no Emprego (CITE).

Hannerz, Ulf (1998), Conexiones Transnacionales. Cultura, Gente, Lugares, Madrid, Ediciones Cátedra. 
Henriques, Joana Gorjão (2015), “Os polícias disseram que nós, africanos, temos de morrer", Público On-line, 10/02/2015, consultado a 23/05/2015 em:

http://www.publico.pt/sociedade/noticia/os-policias-disseram-que-nos-africanos-te mos-de-morrer-1685599

Hobsbawm, Eric (1984), "Introdução: a invenção das tradições”, em Eric Hobsbawn e Terence Ranger (orgs.), A Invenção das Tradições, Rio de Janeiro, Paz e Terra, pp. 9-23.

Horta, Ana Paula Beja (2008), A Construção da Alteridade. Nacionalidade, Políticas de Imigração e Acção Colectiva Migrante na Sociedade Portuguesa Pós-Colonial, Lisboa, Fundação Calouste Gulbenkian.

Huq, Rupa (2003), “Global youth cultures in localized spaces: the case of the UK new Asian dance music and French rap", em David Muggleton e Rupert Weinzierl (orgs.), The Post-Subcultures Reader, Oxford, Berg Publishers, pp. 195-208.

INE (2013), “Censos 2011 - população residente por freguesia”, Lisboa, Instituto Nacional de Estatística, CAOP 2013 (CSV), consultado a 14/05/2014.

Kiwan, Nadia, e Ulrike Hanna Meinhof (2011), “Music \& migration: a transnational approach", em Music \& Arts in Action, 3 (3) ("Introduction to the special issue").

Lahon, Didier (2004), “O escravo africano na vida económica e social portuguesa do antigo regime", Africana Studia, 7, pp. 73-100 (Faculdade de Letras da Universidade do Porto).

Leeds, Anthony, e Elizabeth Leeds (1978), A Sociologia do Brasil Urbano, Rio de Janeiro, Jorge Zahar Editor.

Lopes, Baltasar (2008), Chiquinho, Lisboa, Biblioteca Editores Independentes/Cotovia.

Lopes, João Teixeira (2000), A Cidade e a Cultura. Um Estudo sobre Práticas Culturais Urbanas, Porto, Afrontamento.

Maffesoli, Michel (2007), “Tribalism and hospitality”, em Jorge Larrosa (org.), On Generations. On Coexistence between Generations, Barcelona, Fundació Viure i Conviure, pp. 377-379.

Magnani, José Guilherme Cantor (2002), “De perto e de dentro: notas para uma etnografia urbana", Revista Brasileira de Ciências Sociais, 17 (49), pp. 11-29.

Margulis, Mario, e Marcelo Urresti (1996), “La juventud es más que una palabra”, em Mario Margulis e Marcelo Urresti (orgs.), La Juventud Es Más Que Una Palabra. Ensayos sobre Cultura y Juventud, Buenos Aires, Biblos, pp. 13-30.

Matriz PCI (2015), “Ficha de património imaterial (Kola San Jon)”, consultado a 09/06/2015 em: http://www.matrizpci.dgpc.pt/MatrizPCI.Web/Inventario/Inventario Consultar.aspx?IdReg=337

Mauger, Gérard (2013), "Juventude: idades da vida e gerações", Dados - Revista de Ciências Sociais, 56 (1), pp. 169-183.

Mead, Margaret (1990), Adolescencia y Cultura en Samoa, Barcelona, Paidós.

Miguel, Ana Flávia (2010), Kola San Jon, Música, Dança e Identidades Cabo-Verdianas, Aveiro, Universidade de Aveiro, dissertação de mestrado em Música.

Monteiro, César Augusto (2011), Música Migrante em Lisboa. Trajectos e Práticas de Músicos Cabo-Verdianos, Lisboa, Editora Mundos Sociais.

Nico, Magda, Rita Rosado, e Sara Duarte (orgs.) (2007), Licença para Criar. Imigrantes nas Artes em Portugal, Lisboa, ACIME. 
OIT - Organização Internacional do Trabalho (2016), Guy Ryder Announces Global Youth Initiative, consultado a 10/03/2016 em:

http://www.ilo.org/global/about-the-ilo/newsroom/news/WCMS_447516/lang-en/ index.htm

Oliveira, Catarina Reis, e Natália Gomes (orgs.) (2014), Monotorizar a Integração de Imigrantes em Portugal. Relatório Estatístico Decenal, Lisboa, ACM.

Pais, José Machado (1993), Culturas Juvenis, Lisboa, Imprensa Nacional Casa da Moeda.

Pais, José Machado (2009), “A juventude como fase de vida: dos ritos de passagem aos ritos de impasse", Saúde e Sociedade, 18 (3), pp. 371-381.

Pires, Rui Pena (2003), Migrações e Integração, Oeiras, Celta Editora.

Pozo, Maritza (2012), “De jóvenes contemporáneos: trendys, empreendedores y empresarios culturales", em Néstor Canclini, Francisco Cruces e Maritza Pozo (orgs.), Jóvenes, Culturas Urbanas y Redes Digitales, Barcelona, Ariel, pp. 25-44.

Pujadas, Joan J., e Gaspar Maza (2018), “Daily mobility and urban sprawl: mobile ethnography in the metropolitan region of Barcelona (MRB)", em Lígia Ferro, Marta Smagacz-Poziemska, M. Victoria Gómez, Sebastian Kurtenbach, Patrícia Pereira e Juan José Villalón (orgs.), Moving Cities. Contested Views on Urban Life. Berlim, Springer Verlag, pp. 43-60.

Raposo, Otávio (2005), “Sociabilidades juvenis em contexto urbano: um olhar sobre alguns jovens do Bairro Alto da Cova da Moura", Fórum Sociológico, 13-14 (2), pp. 151-170.

Raposo, Otávio (2010), “Tu és rapper, representa Arrentela, és red eyes gang: sociabilidades e estilos de vida de jovens do subúrbio de Lisboa", Sociologia, Problemas e Práticas, 64, pp. 127-147.

Raposo, Otávio (2015), "Violência e racismo na Cova da Moura”, Rede Angola, 11/02/2015, consultado a 10/05/2016, em: http://www.redeangola.info/especiais/violencia-e-covardia-na-cova-da-moura/

Sansone, Livio (2007), Negritude sem Etnicidade. O Local e o Global nas Relações Raciais e na Produção Cultural Negra do Brasil, Salvador, Edufba.

SEF - Seviço de Estangeiros e Fronteiras (2014), Relatório de Imigração. Fronteiras e Asilo, 2014, Lisboa, SEF, consultado a 26/06/2015, em: http://sefstat.sef.pt/Docs/Rifa_2014.pdf

Sieber, Timothy (2005), "Popular music and cultural identity in the Cape Verdean post-colonial diaspora", Etnográfica, IX (1), pp. 123-148.

Tinhorão, José Ramos (1997), Os Negros em Portugal. Uma Presença Silenciosa, Lisboa, Caminho.

Vaz, Cláudia, e Ricardo Campos (2013), “Rap e graffiti na Kova da Moura como mecanismos de reflexão identitária de jovens afrodescendentes", Sociedade e Cultura, disponível em: http://www.redalyc.org/html/703/70329744013/ (última consulta em 05/07/2016).

Velho, Gilberto (1994), Projeto e Metamorfose: Antropologia das Sociedades Complexas, Rio de Janeiro, Jorge Zahar Editor.

Vianna, Hermano (org.) (1997), Galeras Cariocas. Territórios de Conflitos e Encontros Culturais, Rio de Janeiro, Editora UFRJ.

Yúdice, George (2007), Nuevas Tecnologías, Música y Experiencia, Barcelona, Editorial Gedisa. 
Pedro Varela. Investigador júnior do Centro de Estudos Sociais da Universidade de Coimbra (CES-UC). No momento de desenvolvimento da pesquisa que aqui se reporta, Pedro Varela era bolseiro do Instituto Universitário de Lisboa (ISCTE-IUL), Centro de Investigação e Estudos de Sociologia (CIES-IUL), Lisboa, Portugal. E-mail: pedromfvarela@gmail.com

Otávio Raposo. Investigador pós-doutorado do Instituto Universitário de Lisboa (ISCTE-IUL), Centro de Investigação e Estudos de Sociologia (CIES-IUL), Lisboa, Portugal. E-mail: raposao78@gmail.com

Lígia Ferro. Investigadora do Instituto de Sociologia da Universidade do Porto (IS-UP) e professora auxiliar da Faculdade de Letras da Universidade do Porto (FLUP). À data da realização do estudo, Lígia Ferro era investigadora pós-doutorada do Instituto Universitário de Lisboa (ISCTE-IUL), Centro de Investigação e Estudos de Sociologia (CIES-IUL), Lisboa, Portugal. E-mail: lferro@letras.up.pt

Receção: 06 de outubro de 2015 Aprovação: 13 de dezembro de 2016 